\title{
OSPREY makes waves in UK energy research
}

London. The launch of the world's first commercial wave-power station in Scotland earlier this month may reopen the debate about the wisdom of the British government's decade-long suspension of long-term funding for wave energy studies.

The $£ 1.9$ million Ocean Swell Powered Renewable Energy generator (OSPREY) has been developed by the Inverness-based company Applied Research and Technology Ltd. The company raised $£ 435,000$ (US\$696,000 of the costs needed from the European Union's Joule non-nuclear energy research programme, and the remainder from private companies including AEA Technology, Scottish Hydroelectric and GEC Alsthom. British Steel donated 800 tonnes of steel to the project.

OSPREY, weighs 8,000 tonnes, took five years to develop and is expected to operate for 25 years. It will be installed off the coast of Dounreay, northern Scotland, and will generate $2 \mathrm{MW}$ of electricity, enough power for 2,000 households. Electricity will be carried to land via an undersea cable. A wind turbine carried on the vessel can generate an additional $1.5 \mathrm{MW}$.

The British government provided $£ 50,000$ for water-tank tests of an OSPREY model, but since 1983 has stopped all support for research into wave energy on the grounds that its high initial capital costs would make it uneconomic.

\section{IMAGE UNAVAILABLE FOR COPYRIGHT REASONS}

Ruling the waves: Will Osprey turn the tide in favour of UK wave-energy research.

The government's position was endorsed in 1992, when a feasibility study commissioned from the Department of Trade and Industry's (DTI) Renewable Energy Advisory Group concluded that wave generators "would be unlikely to generate electricity competitively in the short to medium term".

The study's findings were taken up by a review commissioned last year by the DTI, which recommended that the government should maintain the freeze on funding. Tim Eggar, the minister for energy, subsequently confirmed, in a written reply to a question in the House of Commons, that no money would be available for wave power, which he said had "limited potential to contribute commercially to energy supplies".

David Ross, an environmental journalist,
E and author of a forthcoming book Power from the waves, disputes the government's conclusions: "How can wave power be considered expensive?" he asks. "All the costs are in the beginning, after that, it is free."

ن The United Kingdom has 12,000MW of potentially usable wave power, equivalent to the installed generating capacity of Scotland. According to Ross, "wave-power research was sacrificed because the government wanted to develop nuclear power. It was a political decision".

Meanwhile, researchers at the University of Edinburgh have won an ECU800,000 (US\$1.05 million) grant from the Joule programme to develop a hub for a two-tonne turbine blade for a wave generator destined for the Azores islands in the Atlantic Ocean. Stephen Salter, professor of engineering design at the university, says the development of OSPREY represents "a huge loss of face" for the British government. "It is a considerable achievement to get private money in the face of opposition from your own government."

The OSPREY project, Salter believes, represents a milestone in renewable energy research. "It has the same significance as the Blériot flight across the English Channel," he asserts. "Few at the time believed that air travel was possible, fewer still were prepared to back the project. But it still succeeded."

Ehsan Masood

\section{Corn crosses last hurdle for genetically modified crops}

Oxford, UK. The US Environmental Protection Agency (EPA) has approved applications from two companies to market for the first time corn seeds genetically engineered to produce pesticides against the European corn borer, a pest that causes losses of around US\$1 billion annually to farmers in the United States.

The approval, granted to the US agricultural biotechnology company Mycogen Corporation and the Swiss company Ciba Seeds, clears the way for commercial use by next year of the transgenic corn seeds. These contain a gene from the soil bacterium Bacillus thuringiensis (Bt) that produces a protein that is toxic to insect pests such as the European corn borer.

This EPA approval is the final regulatory hurdle for the modified corn, as the US Food and Drug Administration has cleared it on safety grounds.. The US Department of Agriculture, meanwhile, says it will treat genetically modified corn seeds in the same way as corn hybrids bred by conventional means.

Advocates of agricultural biotechnology argue that such modified hybrids will reduce or eliminate the need for conventional chemical insecticides. The comp-

\section{IMAGE UNAVAILABLE FOR COPYRIGHT REASONS}

Field day: Genetically-engineered corn will eliminate the need for chemical insecticides.

anies expect Bt-modified seed to capture a significant share of the \$2-billion US seedcorn market.

Bacillus thuringiensis is not a stranger to pest control. Organic farmers have been spraying it on crops as a natural pesticide for several decades. The Union of Concerned Scientists is worried that constantly exposing corn borers to $\mathrm{Bt}$ at the levels at which corn is grown will increase the likeli-
음 hood that the pests will develop resistance. Mindful of these concerns, the EPA has t included conditions in the approval ordering the companies to monitor insect resistance, and to conduct research to develop resistance management plans and to develop plans should the insects become resistant.

Jerry Caulder, chief executive of Mycogen, says the likelihood of increased resistance has been reduced because the company's transgenic corn seed contains both natural and Bt-based control genes. This combination, he says, is a key element of a resistance-management programme his company has developed to protect Bt's long-term effectiveness in crop protection.

The EPA approval does not open the door for biotech corn-on-the-cob or popcorn just yet, however, as the EPA registration is limited to commercial field corn production. It is possible that some modified corn might be used in the production of high-fructose corn syrup, a sweetener used by the soft drinks industry. EPA officials will evaluate the companies' compliance with registration requirements and decide whether to allow full commercialization in five years.

Mike Ward 